\title{
Island Of Circe : Power Struggle and Harold Pinter
}

\author{
Monishikha Mukherjee \\ Dept of Humanities, Budge budge Institute of Technology/WBUT, India
}

\begin{abstract}
Having lived through world war 2, having experienced numerous confrontations with Fascist gangs, and having acted as a "conscientious objector", and having been alert to world affairs, Harold Pinter developed strong hatred toward all forms of injustice. Eventually this led to his lifelong cynicism about politicians, hypocrisy of governments and violation of human rights all over the world, exposing British and American policies in the Balkans, Afghanistan and Iraq, among others.

This paper seeks to address the following question: given that Pinter repeatedly focuses his dramatic attention on menace, violence and the struggle for power, how does our knowledge that he actively opposed all such political manifestations of these phenomena influence our understanding of his work?

The main objective of this study is to depict how Pinter has attempted to envisage the abuse of power by those who hold it in order to dominate and subjugate the people
\end{abstract}

Keywords - Politics, Power, Abuse, Fascism, Harold Pinter, Human Rights

\section{Introduction}

This paper seeks to address the following question: given that Pinter repeatedly focuses his dramatic attention on menace, violence, intrusion, and the struggle for power, how does our knowledge that he actively opposed all such political manifestations of these phenomena influence our understanding of his work? The given paper examines Pinter's public acts and preoccupation with sensitivity to the violation of political language and the issue of democracy, both in life and art. His late theatrical plays, which are still produced around the world, are admired not just for their verbal precision, but also for their political resonance.

\section{Pinter's Struggle Against Power Struggle}

The politics of Harold Pinter's work are not derived from any ideological affinity with a specific political position, or indeed from any clearly defined ideological base or contemporary party politics. Pinter's dramatic and poetic works do not scrutinize government politics or rail against those politics in a thinly veiled dramatic polemic [1] Pinter's work is not the product of the "angry playwright" that the popular media chose to designate him as.

His work is no propaganda machine or part of any ideological 'ism' because a work of art goes beyond such ideological stances .Yet he vigorously and incessantly protested against all types of oppressions and the abuse of power .His plays (One for the Road, The Hothouse, The Dumb Waiter, The New World Order, Mountain Language, The Birthday Party and Party Time) are the best evidence of his obsession with power. Most of these plays are portrayals of the methods of torture, corruption and the abuse of power .Pinter's plays illustrate the ability of power to corrupt.

\section{Oppressions Are Beyond Boundaries}

The abuse of power, pre- occupation with authority and corruption are major themes that may be traced in almost all of Pinter's plays. The political plays show the characters' private fantasy worlds as a massive and historically important objective reality. Space is unspecified, deliberately unlocalised; it is global, because Pinter did not want to reduce the plays' meaning to certain countries, but rather he interrogated borders, and boundaries in an alarming vast, incomprehensible world.

His political dramas frame the relationship between fictional and empirical reality as Pinter clarifies and reworks his earlier themes of oppression and the individual and the subversive function of language.

He writes of the inhuman character of a great city poisoned by misery, contempt and oppression .Pinter transfers menace from private relationships to expressively political ones. In all of these plays the longing for individual freedom is walled in by a social institution that is an over determined and a closed system .Pinter has stated that 'each of the plays dealt with the individual at the mercy of a certain authoritarian system'.

Pinter's observations and explorations in an alarming world convinced him of the duty to depict and criticize authoritarian forces and oppressive institutions through his art .In particular he reflects on the way established systems of society project images onto individuals [2]. 


\section{Magical Spell of the Witch Named Power}

Pinter shows us how those who are in power treat the individuals in an institution or society; how even the victimizer becomes a victim in an authoritarian system .Thus power leads to bureaucracy and corruption .In this light Pinter's characters are not villains but anyone who is in a powerful position can be aggressive and try to dominate the others. Thus the abuse of power and power struggles has obsessed Pinter for his entire life. Pinter's plays envisage how power creeps in everywhere in society and how it tries to subjugate and control those who do not comply with the power system.

\section{Pinter - The Sailor Of Ulysses}

Pinter's biographer Michael Billington has properly observed 'Pinter's vision of human relationships as a quest for dominance and control in which the power balance is capable of reversal.'(Billington, 2007 Rev. Ed). Yet in his often outspoken political stands- against the first Gulf war, the NATO intervention in Kosovo etc . - he argued forcefully against the national forms of violence, power, and intrusion that he examines , on a personal level, in his plays .

His politics is that of a struggle between power and powerlessness, induced by an "instinctive moral rage" against any injustice which strives to erode the validity of the individual .Pinter's politics is premised on power-structured relationships and, in particular, how social relations involving authority and power threaten the autonomy and importance of the individual. Pinter's individuals, from The Caretaker's Davies, to Party Time's Jimmy, are established through the creation of individual identities that subvert generic classifications such as name, racial group or nationality. These broad classifications, which compromise individual identity, are undermined throughout Pinter's work through establishing the importance of the voice of the individual. Through their involvement in political power struggles and relationships, Pinter's individuals struggle to retain their sense of self.

\section{Conclusion}

Pinter forays into explicitly 'political' drama with plays which addressed the abuse of human rights, the oppression of minorities and bourgeois complicity in governmental violence. His reflection, in 1989, suggests that his plays were always concerned with 'the relationship between the state and the individual and how the self-perpetuating concerns of the former often obscure and override the dignifying rights of the latter' (Batty, 2001b: 91). It is this relationship which has made him recognizably 'political', and indeed the plays which were once coined 'Absurd', The Birthday Party, The Dumb Waiter and The Caretaker, are now featured heavily in politically themed criticism of Pinter's work.

\section{Books:}

\section{REFERENCES}

[1] Mel Gussow : conversation with pinter (New York: Limelight, 1994)

[2] Martin Esslin: pinter: a study of his plays (London; Methuen, 1977). 